\title{
Recorregut paripatètic de recerca geològica per la comarca del Vallès Occidental: des de Castellar del Vallès al Puig de la Creu, al Coll Roig i al Coll de Canyelles
}

Josep Maria Mata-Perelló

Joaquim Sanz Balagué

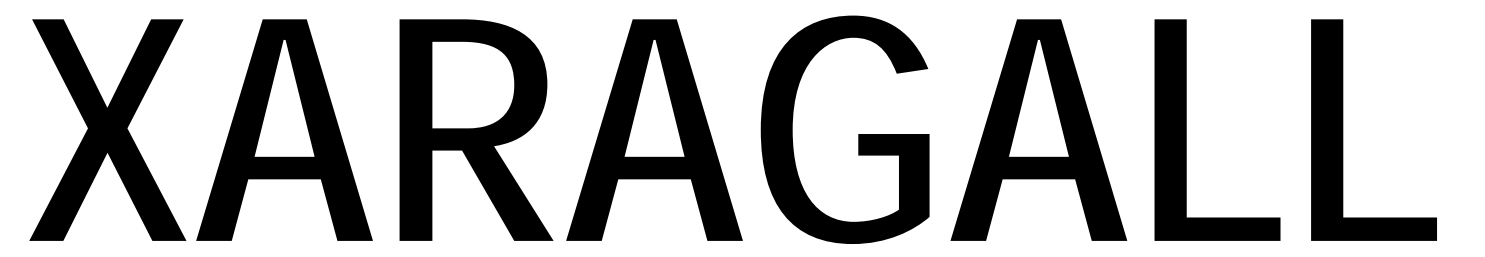

REVISTA DE CIÈNCIES DE LA CATALUNYA CENTRAL

\section{n. 2}

FEBRER 2015 


\title{
RECORREGUT PARIPATÈTIC DE RECERCA GEOLÒGICA PER LA COMARCA DEL VALLÈS OCCIDENTAL: DES DE CASTELLAR DEL VALLĖS AL PUIG DE LA CREU, AL COLL ROIG I AL COLL DE CANYELLES
}

\author{
Josep Maria Mata-Perelló \\ Museu de geologia Valentí Masachs, Escola Politècnica Superior d'Enginyeria de Manresa \\ (EPSEM), Universitat Politècnica de Catalunya · BarcelonaTech (UPC), 08272 Manresa, Spain
}

Joaquim Sanz Balagué

Departament d'Enginyeria Minera i Recursos Naturals (EMRN), Escola Politècnica Superior d'Enginyeria de Manresa (EPSEM), Universitat Politècnica de Catalunya - BarcelonaTech (UPC), 08272 Manresa, Spain

Paraules clau: Sistema Mediterrani, Patrimoni miner

\section{Resum}

Itinerari realitzat el 16 de febrer de 2014. En aquesta ocasió, el recorregut de l'itinerari discorrerà, en la seva totalitat pel Sistema Mediterrani, i més concretament per la Serralada Prelitoral Catalana (la seva unitat més externa). Així doncs, la quasi totalitat del recorregut per les vessants del Puig de la Creu, dintre sempre d'aquesta unitat geològica.

Per altra banda, i com ja s'entreveu al títol, el recorregut de l'itinerari discorrerà sols per la comarca del Vallès Occidental, pels termes municipals de Castellar del Vallès i de Sant Llorenç Savall, en la seva totalitat, també. 


\section{Objectius fonamentals}

Els objectius fonamentals que es pretenen aconseguir en aquest itinerari, es poden concretar en els següents aspectes generals:

1. Observació i descripció dels materials mesozoics (del Triàsic, exclusivament) i paleozoics (fonamentalment de I'Ordovicià) de la Serralada Prelitoral Catalana (integrant del Sistema Mediterrani) que es troben al llarg de bona part del recorregut de l'itinerari.

2. Observació i descripció dels materials cenozoics (del Paleocè i de I'Eocè, de la Depressió Geològica de l'Ebre, que es troben al llarg de bona part dels darrers trams de recorregut de l'itinerari.

3. Observació de les estructures locals d'aquests materials, al llarg del recorregut de l'itinerari. Així com de les relacions entre les diferents unitats geològiques on es troben situades.

4. Observació de les explotacions mineres que anirem trobant al llarg del recorregut. Fonamentalment es tracta de les explotacions de les calcaries triàsiques del Muschelkalk Inferior.

5. Observació, si s'escau, de les restauracions realitzades a les explotacions mineres, per tal reduir l'impacte ambiental. I en el seu defecte: observació de l'impacte produït per les explotacions mineres.

6. Observació dels diferents elements del Patrimoni Geològic (i si s'escau del Patrimoni Miner), que es vagin trobant al llarg del recorregut de l'itinerari.

\section{Antecedents}

Pel que fa al recorregut del present itinerari, cal dir que no hem sabut trobar cap antecedent bibliogràfic publicat, en relació al mateix. Nosaltres mateixos, és la primera vegada que realitzem un recorregut geològic per aquests indrets.

Pel que fa a la descripció de les mineralitzacions, farem esment del treball del mateix autor del present itinerari, Mata Perelló (1991), relatiu al conjunt de les mineralitzacions catalanes.

I, finalment, pel que fa a l'estructura geològica de la zona per la qual discorre l'itinerari, farem esment dels treballs de: Guimerà et altri (1982) i de Riba et altri (1976); així com del full 392 de I'IGME (1976).

Tots aquests treballs referenciats, i d'altres, figuren esmentats per ordre alfabètic a l'apartat dedicat a la BIBLIOGRAFIA. 


\section{Recorregut de l'itinerari}

La totalitat del recorregut de l'itinerari es situarà dintre de la comarca del Vallès Occidental. És més, la pràctica totalitat del mateix es realitzarà exclusivament pels termes municipals de Castellar del Vallès i de Sant Llorenç Savalı, tot i així, sols entrarem en aquest terme en els darrers trams del recorregut de l’itinerari.

Així, s'iniciarà al mateix poble de Castellar del Vallès (i més concretament des del Carrer del Puig de la Creu), ens caldrà prendre el camí que condueix cap el Puig de la Creu. Tot seguit, després d'arribar al seu cim, ens caldrà continuar cap el Coll Roig, per tal d'arribar posteriorment fins al Coll de Canyelles, per om finalitzarà el recorregut d’aquest itinerari.

\section{Advertiments previs}

Com en altres recorreguts de RECERCA GEOLÒGICA I MINERALÒGICA... si es disposa del temps suficient, poden efectuar-se passant per totes les parades i filloles. En cas contrari, recomanem prescindir de les anomenades PARADES - CONDICIONALS.

En aquest itinerari, la totalitat del mateix es realitzarà per camins de muntanya i també per alguns trams de carretera; encara que en aquest cas serà mínim.

Com en tots els altres itineraris, recomanem tenir una cura molt especial de respecte a la natura, al llarg de tot el recorregut del mateix.

\section{Descripció de l'itinerari}

Com de costum, estructurarem el recorregut de l'itinerari en una sèrie de PARADES, que tot seguit anirem veient. En cadascuna d'aquestes aturades farem un breu comentari. En cada cas indicarem, entre parèntesi, el full topogràfic on es troba l'aturada, i la designarem amb el nom d'algun topònim proper, fent esment també del terme municipal on es troba situada.

Cal dir que el recorregut de l'itinerari s'inclourà totalment dintre del full no 392 (o de Sabadell), del "Mapa Topográfico Nacional", realitzat a l'escala 1:50.000 per I'Instituto Geográfico y Catastral de España. També s'utilitzarà el mapa comarcal del Vallès Oriental, a escala 1:50.000, editat per l'Institut Cartogràfic de Catalunya.

Així, les diferents aturades que anirem trobant al llarg del recorregut, d’acord amb el seu ordre, seran les següents. 


\subsection{Parada 1 - CONDICIONAL. IMMEDIACIONS DE LA ROTONDA DE LA CARRETERA A SENTMENAT, CAMÍ CAP EL TURÓ DEL PI GRÓS, BARRI DELS FRUITERS, (terme municipal de Castellar del Vallès, comarca del Vallès Occidental). (Full 392).}

El recorregut del present itinerari l'iniciarem per les proximitats de la rotonda de la carretera autonòmica $C-1415 a$, en el seu sentit xap a Sentmenat. Així, per les immediacions d'aquest indret, sortint lleugerament de Castellar del Vallès pel camí que es dirigeix cap el Turó del Pi Gros, farem la primera aturada.

Aquest indret, es troba totalment situat dintre de la Serralada Prelitoral Catalana (la unitat més externa del Sistema Mediterrani), encara que molt a prop de la Depressió Prelitoral Catalana, situada al Sud d'on ara som i es fa palesa al Turó del Pi Gros.

En aquest indret afloren els materials granítics del Carbonífer, de l'esmentada serralada. Es tracta de roques plutòniques molt alterades, convertides en sauló, com a conseqüència de la transformació per la meteorització química, dels feldspats de la roca ígnia en caolí. Aquesta meteorització produeix l'esmicolament de la roca inicial, convertint-se en una sorra de gra gruixut.

Tot i així, bona part de l'aflorament es troba recobert per sediments recents de l'Holocè, de derrubis de pendent. (fotografia 1 ).

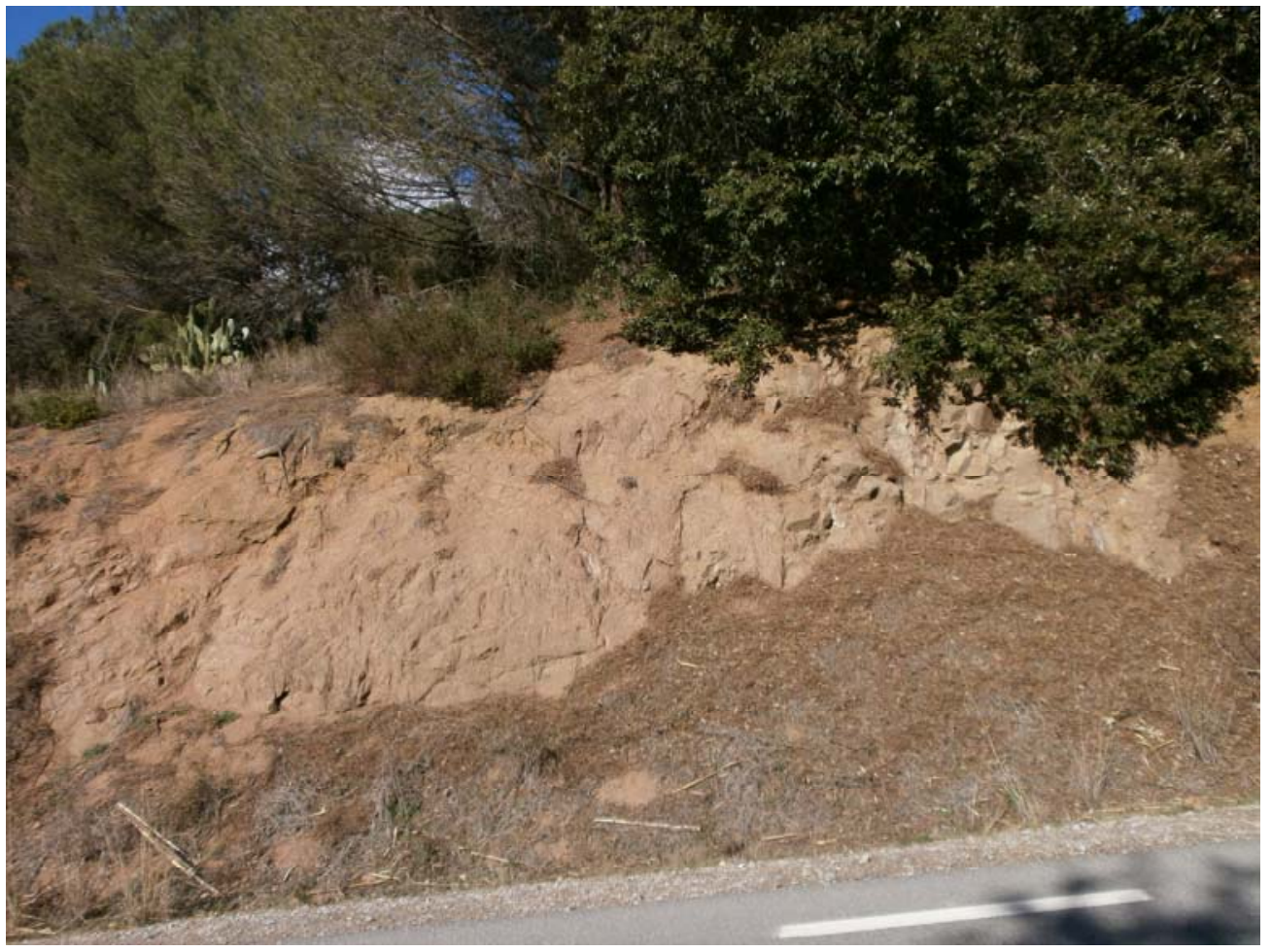

Fotografia 1. Aflorament dels granits del Carbonífer, alterats i convertits en sauló. Castellar del Vallès 
Per altra banda, des d'aquest indret es pot gaudir d'una bona visió del Puig de la Creu. (fotografia 2)

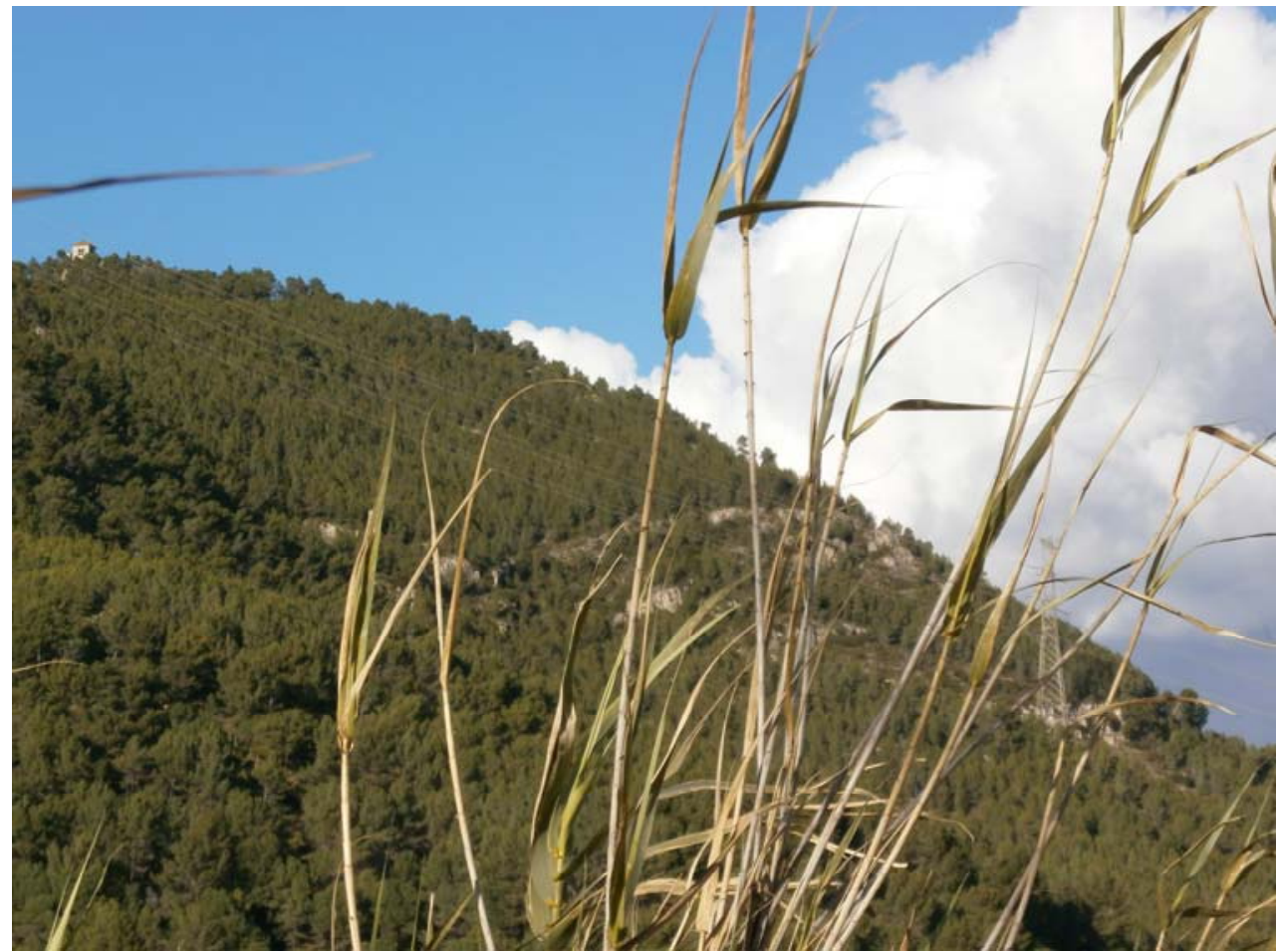

Fotografia 2. El Puig de la Creu, des del Barri dels Fruiters. Es pot observar l'aflorament dels nivells carbonatats del Muschelkalk Inferior. Castellar del Vallès

\subsection{Parada 2 - CONDICIONAL. IMMEDIACIONS DE L'ESCOLA "EL CASAL", (terme municipal de Castellar del Vallès, comarca del Vallès Occidental). (Full 392).}

Després de realitzar l'aturada anterior, cal anar lleugerament cap el Nord, en direcció al Barri dels Fruiters, entrant a la part alta de Castellar del Vallès. Per aquest indret del barri, podem fer una nova aturada, si s'escau, a menys de $0^{\prime} 5 \mathrm{Km}$ de la parada anterior. Un bon indret és per les immediacions de l'Escola "El Casal"

En aquest curt recorregut, hem estat circulant per una zona urbanitzada, per la qual cosa es gairebé impossible veure els afloraments. Tot i així, per la base del Puig de la Creu, es van fent evidents uns afloraments dels materials rogencs del Buntsandstein (del triàsic Inferior), Es tracta de la presència de nivells de gresos, lutites i calcolutites de tonalitats rogenques. (fotografia 3). 


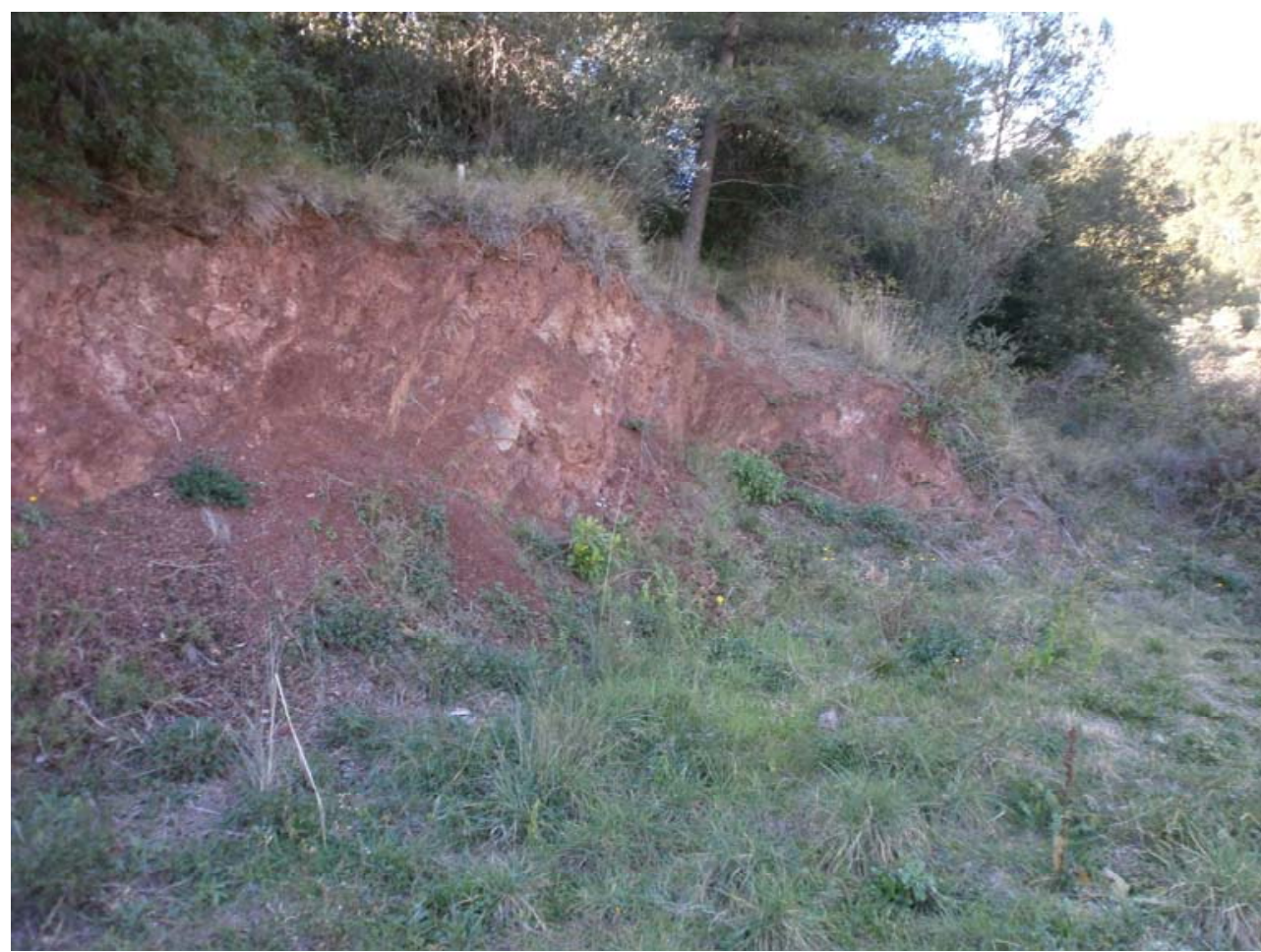

Fotografia 3. Aflorament dels gresos rogencs i de les lutites del Buntsandstein. Castellar del Vallès

\subsection{Parada 3. PEDRERA DEL SOT D’EN GOLERES, (terme municipal de Castellar del Vallès, comarca del Vallès Occidental). (Full 392).}

Després d'efectuar l'aturada anterior, cal anar cap el carrer del Puig de la Creu, des d'on surt un camí ample que es dirigeix cap a l'antiga pedrera del Sot d'En Goleres. En aquest indret farem una nova aturada, a poc més de $1 \mathrm{Km}$ de la parada anterior.

En els primers trams del recorregut, es fan palesos els afloraments de les lutites i calcolutites rogenques del Buntsandstein (fotografia 4). Tot i així, ben aviat es comencen a trobar afloraments dels materials carbonatats del Muschelkalk Inferior, els quals van estar explotats en aquest indret, per tal d'ésser emprats com a àrids per a la construcció. (fotografia 5). 


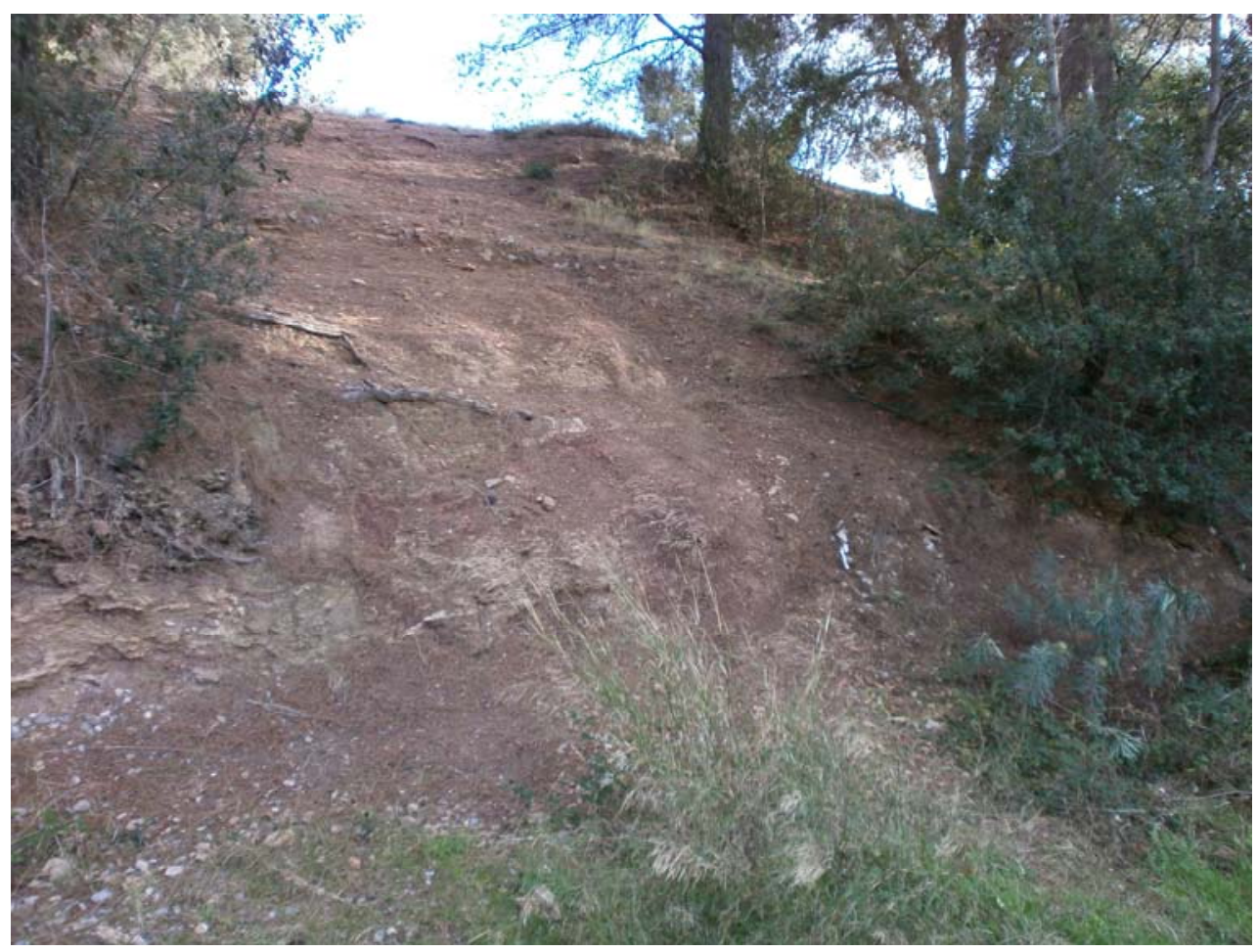

Fotografia 4. Aflorament de les lutites i calcolutites del Bunsadnsteim. Camí cap a la Pedrera del Sot de Goleres. Castellar del Vallès

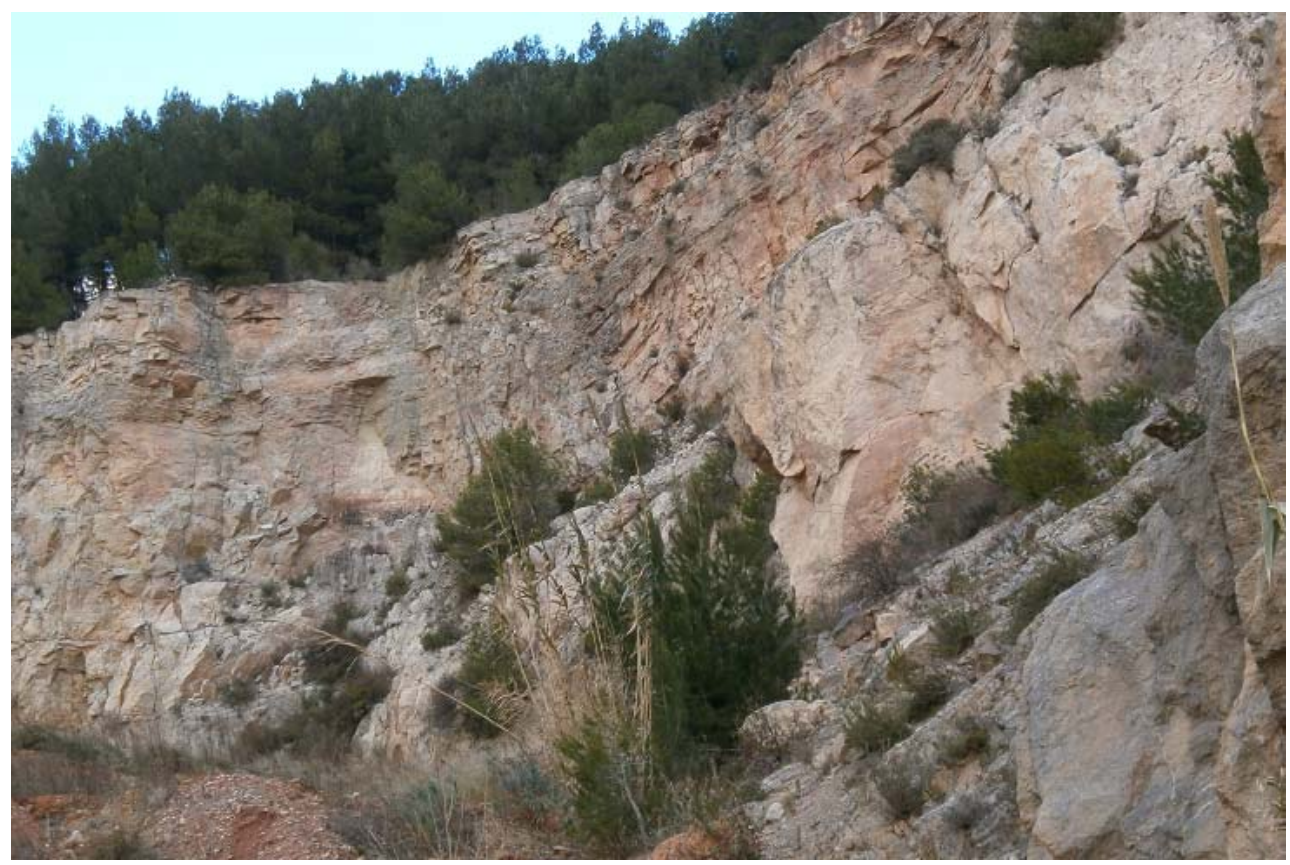

Fotografia 5. Aflorament de les calcàries triàsiques del Muschelkalk Inferior a la Pedrera del sot de Goleres. Castellar del Vallès 
En arribar a l'indret de la present aturada, es fa palesa una antiga explotació (actualment aturada). En ella s'aprofitaven les calcàries triàsiques del Muschelkalk com a matèria prima per a l'obtenció d'àrids per a la construcció.

A l'actualitat, aquesta explotació es troba totalment aturada, amb les seves instal-lacions molt deteriorades i malmeses. Al mateix temps, el medi natural es troba afectat, sense haver-se fet cap restauració ambiental.

Per altra banda, en aquest recorregut, es fa força palès el relleu de Sant Llorenç del Munt 8mirant cap el NW, (fotografia 6). I tanmateix, també es fan paleses les restes del Patrimoni Miner, associat a l'explotació de la pedrera, les quals es conserven en molt mal estat: (fotografia 7).

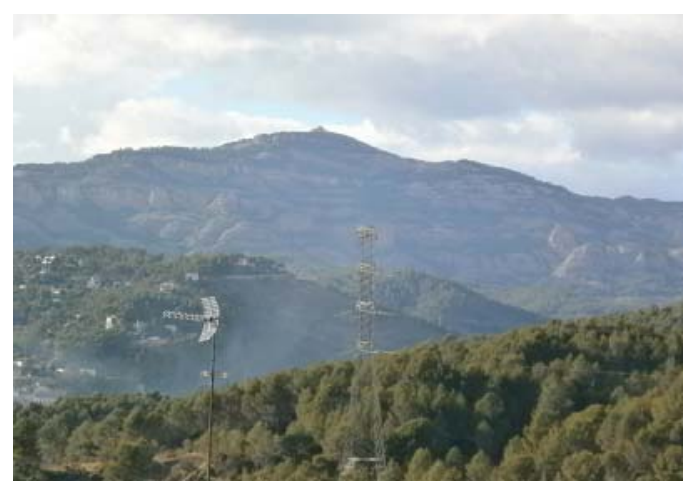

Fotografia 6. Sant Llorenç del Munt. Camí a la Pedrera de Goleres. Castellar del Vallès

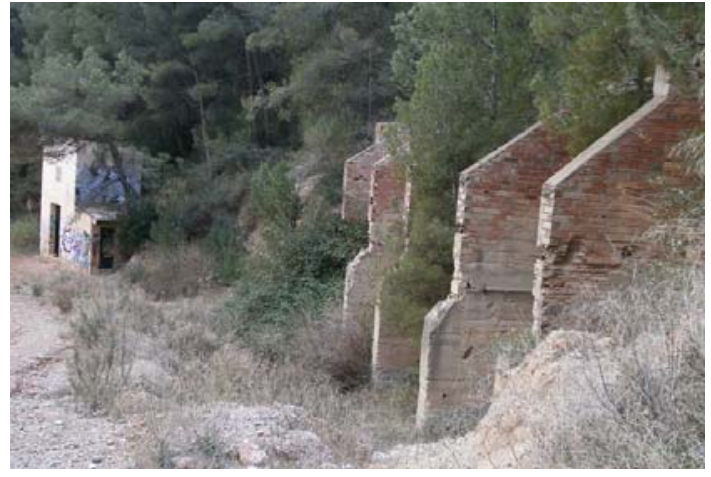

Fotografia 7. Restes del transformador i de les tolves. Pedrera de Goleres. Castellar del Vallès

\subsection{Parada 4. CIM DEL PUIG DE LA CREU, (termes municipals de Castellar del Vallès i de Sentmenat, comarca del Vallès Occidental). (Full 392).}

Després de realitzar l'aturada anterior, cal agafar el camí que des de la Pedrera condueix cap el cim del Puig de la Creu. Així, anirem pujant i en arribar dalt, farem una nova aturada, a poc més de 1'5 Km de l'aturada anterior. Hi pujarem en uns 40 - 45 minuts, aproximadament.

En aquest recorregut, haurem trobat afloraments dels materials carbonatats esmentats anteriorment. Fonamentalment, es tracta de les calcàries del Muschelkalk Inferior, que en ocasions es troben reemplaçades per dolomies. Aquests materials els anirem trobant al llarg de tot el recorregut, encara que passarem prop dels afloraments rogencs del Buntsandstein.

En arribar dalt, trobarem aquests mateixos materials; tot i que apareixen també els nivells rojos del Muschelkalk Mig, amb gresos i calcolutites, fonamentalment; així com ben prop (lleugerament cap el Nord d'on ens trobem) els trams carbonatats del Muschelkalk Superior.

Per altra banda, aquest és un bon indret d'observació. Des d'aquí es pot veure ven clara la Depressió Prelitoral Catalana, situada al Sud i al SE d'on ara ens trobem. També es poden veure els relleus propers del Bosc de Guanta, al nostre NE, entre altres indrets de la Serralada Prelitoral Catalana, on estem ara situats. 


\subsection{Parada 5. EL COLL ROIG, (termes municipals de Castellar del Vallès i de Sentmenat, comarca del Vallès Occidental). (Full 392).}

Tot just després de fer l'aturada anterior, ens caldrà anar cap el Nord, amb la intenció d'arribar fins al paratge del Coll Roig. Després d'un recorregut proper als $1^{\prime} 2 \mathrm{Km}$. Farem una altra aturada.

En aquest recorregut, hem anat trobant els materials dels diferents trams del Muschelkalk. (del Triàsic Mitjà). Així, inicialment haurem vist els nivells carbonatats del Muschelkalk Inferior; després, prop del mateix cim, haurem trobat els gresos rogencs i les calcolutites (també vermelles) del Muschelkalk Mig; i tot seguit, els nivells carbonatats del Muschelkalk Superior.

Tot i així, ben aviat, hem tornat a trobar els materials carbonatats del Muschelkalk Inferior, que ja hem trobat al principi. Aquests materials encavalquen als anteriors i també a uns nivells de calcolutites sorrenques del Paleocè, que trobarem prop de l'indret de I'aturada. Aquests darrers materials pertanyen al Paleocè i a l'Eocè Inferior. Aquest són, precisament els materials que es troben a l'indret de la present aturada, i són els que donen el nom al topònim.

\subsection{Parada 6. COLL DE CANYELLES O LA CADENA, (terme municipal de Castellar del Vallès, comarca del Vallès Occidental). (Full 392).}

Des del Coll Roig, cal fer un nou recorregut, anant de nou cap el Nord (cap el NNW), amb la intenció d'arribar fins al Coll de Canyelles (o de la Cadena). En arribar-hi, farem una nova aturada, després d'un recorregut proper als 2’5 Km, aproximadament, des de la parada anterior.

En aquest recorregut, hem anat trobant els nivells cenozoics del Paleocè i de l'Eocè Inferior, que hem trobat a l'aturada anterior. Aquests materials es troben situats dintre de la Depressió Geològica de l'Ebre. Per les seves característiques es podrien incloure a la Formació Cairat, especialment els nivells de bretxes.

Tot i així, en aquest indret per on farem la present aturada, es poden veure afloraments (molt trinxats) de les pissarres paleozoiques de l'Ordovicià. Aquests materials es fan palesos en veure els derrubis de pendent, fonamentalment. Així, aquests materials es troben encavalcant ala anteriors, als cenozoics que hem estat trobant en tot el camí. Malgrat això, l'encavalcament és molt petit, de reduïda extensió. En realitat es tracta de les restes ailllades d'un encavalcament molt més gran (que possiblement anava des de Matadepera a Sant Feliu de Codines), cobrint materials mesozoics i cenozoics. Després s'hauria erosionat, donant lloc a finestres tectòniques (on es mostra el que havia quedat encavalcat) i klipps tectònics o illes tectòniques (amb restes aïllats de l'encavalcament), com és el cas del Turó dels Tres Pins, entre altres indrets propers. Aquest encavalcament sols es fa palès als derrubis de pendent. (fotografia 8). 


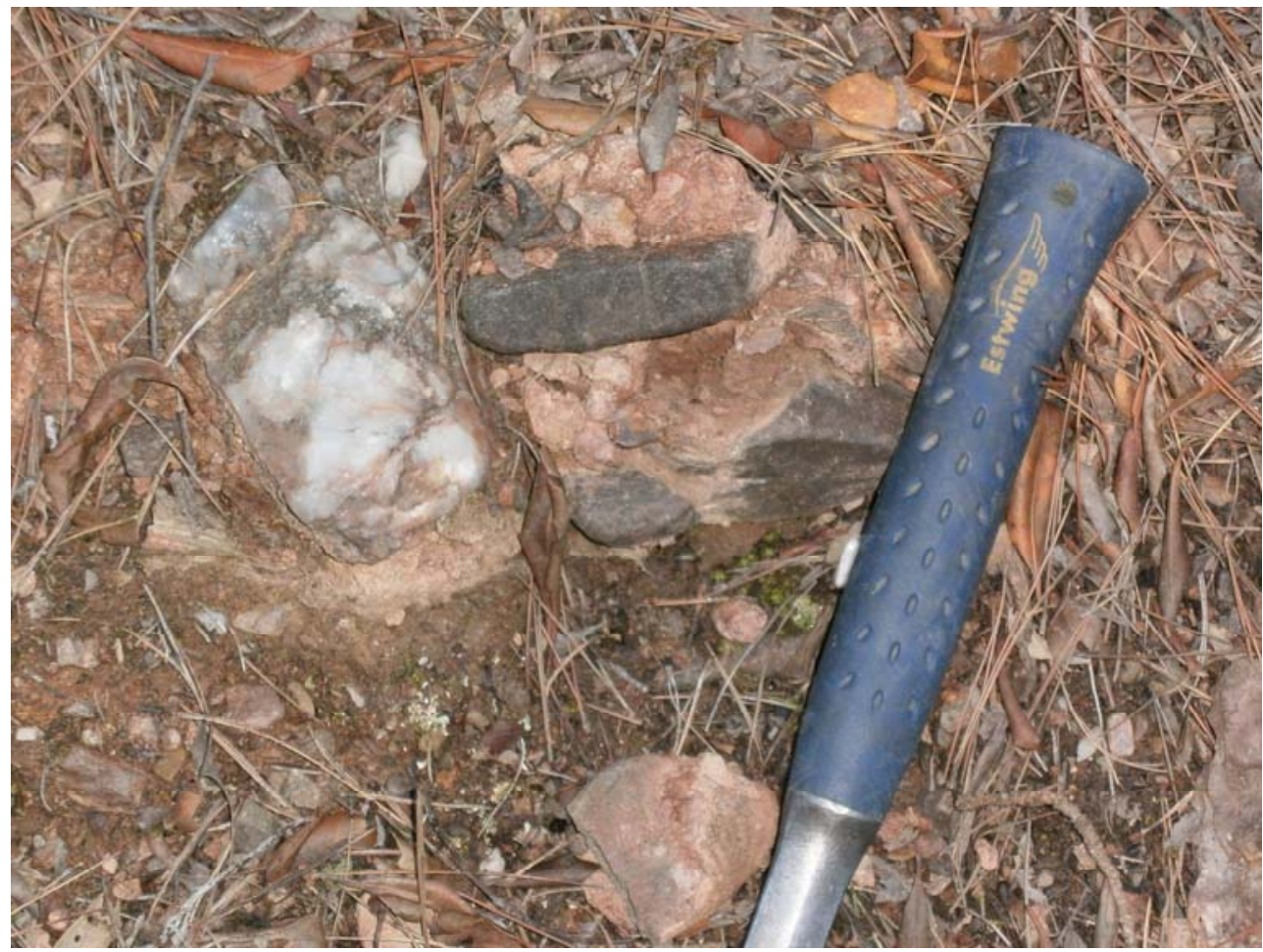

Fotografia 8. Derrubis de pendent del Coll de Canyelles, amb fragment de pissarres i filonets de quars, del Paleozoic. Castellar del Vallès

\subsection{Parada 7 - CONDICIONAL. COLL DE L'ALZINA BALLADORA, (terme municipal de Castellar del Vallès, comarca del Vallès Occidental). (Full 392).}

Després de realitzar l'aturada anterior, cal baixar fins al Coll de I'Alzina Balladora. En aquest indret, si s'escau, es fot fer una nova aturada, en aquesta important cruïlla de camins. Així, haurem recorregut poc més de 0’5 Km.

Des de la parada anterior, fins aquest indret, hem començat a trobar de nou, els afloraments dels materials del Paleocè i de l'Eocè Inferior. Efectivament, hem deixat enrere l'encavalcament, la illa tectònica del Coll de Canyelles. Ara, aquest indret afloren els gresos i les bretxes del Paleocè - Eocè Inferior.

\subsection{Parada 8. IMMEDIACIONS DE CAN CANYELLES, (terme de Castellar del Vallès, comarca del Vallès Occidental). (Full 392).}

Després de fer l'aturada anterior, cal continuar baixant cap a Castellar del Vallès. Així, ens anirem apropant cap a Can Canyelles. Prop de la casa, podem fer una nova aturada. Així, haurem recorregut poc més de 1'5 Km des de la parada anterior.

En aquest recorregut, hem anat trobant afloraments dels materials cenozoics esmentats a l'aturada anterior. Així, sovint es fan palesos els afloraments de les calcolutites i del gresos rogencs (fotografia 9). Altres vegades, com prop de la casa, es fan força palesos els afloraments de les bretxes i conglomerats, els quals sovint formen part de paleocanals, (fotografia 10). 


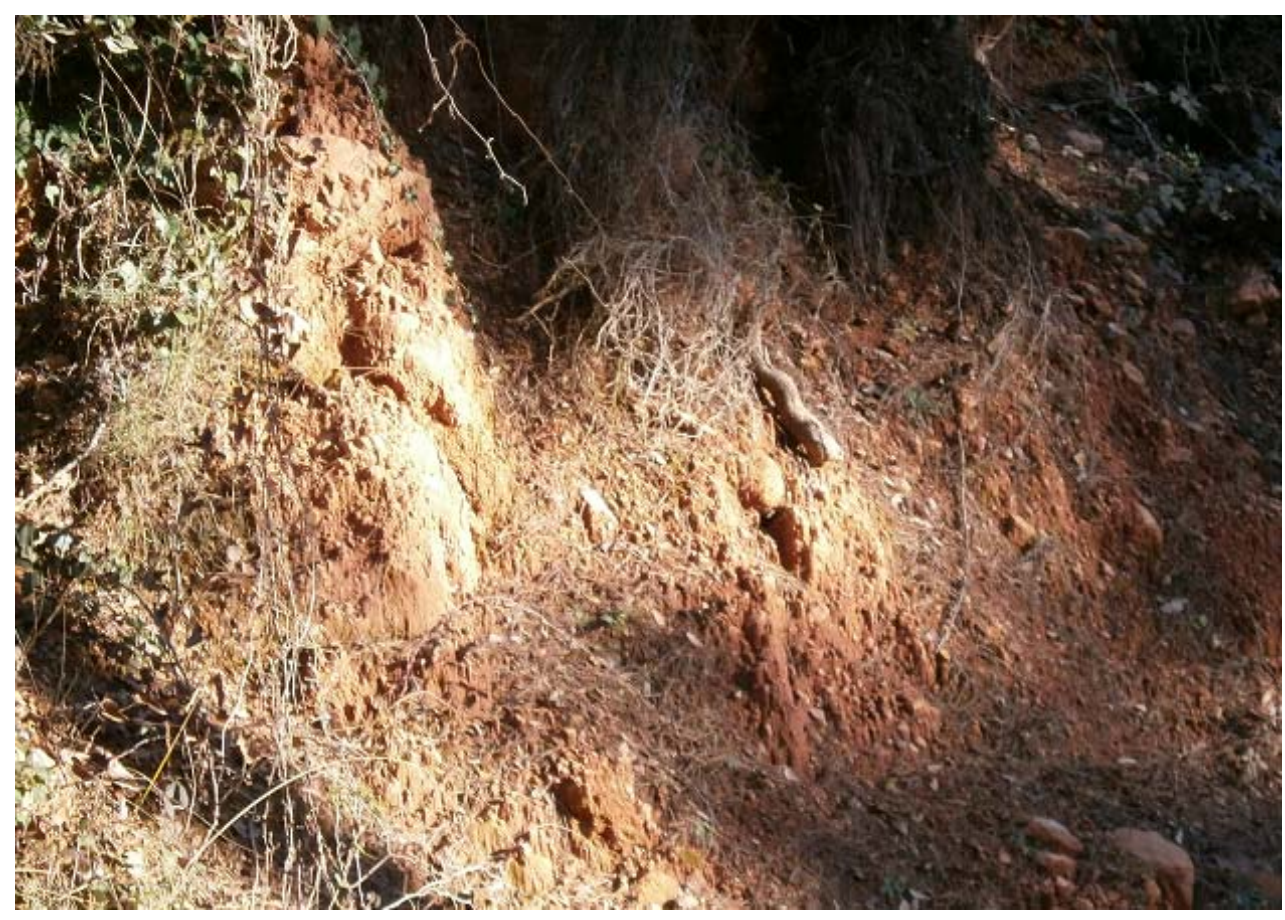

Fotografia 9. Aflorament dels nivells de gresos rogencs de l'Eocè Inferior. Castellar del Vallès

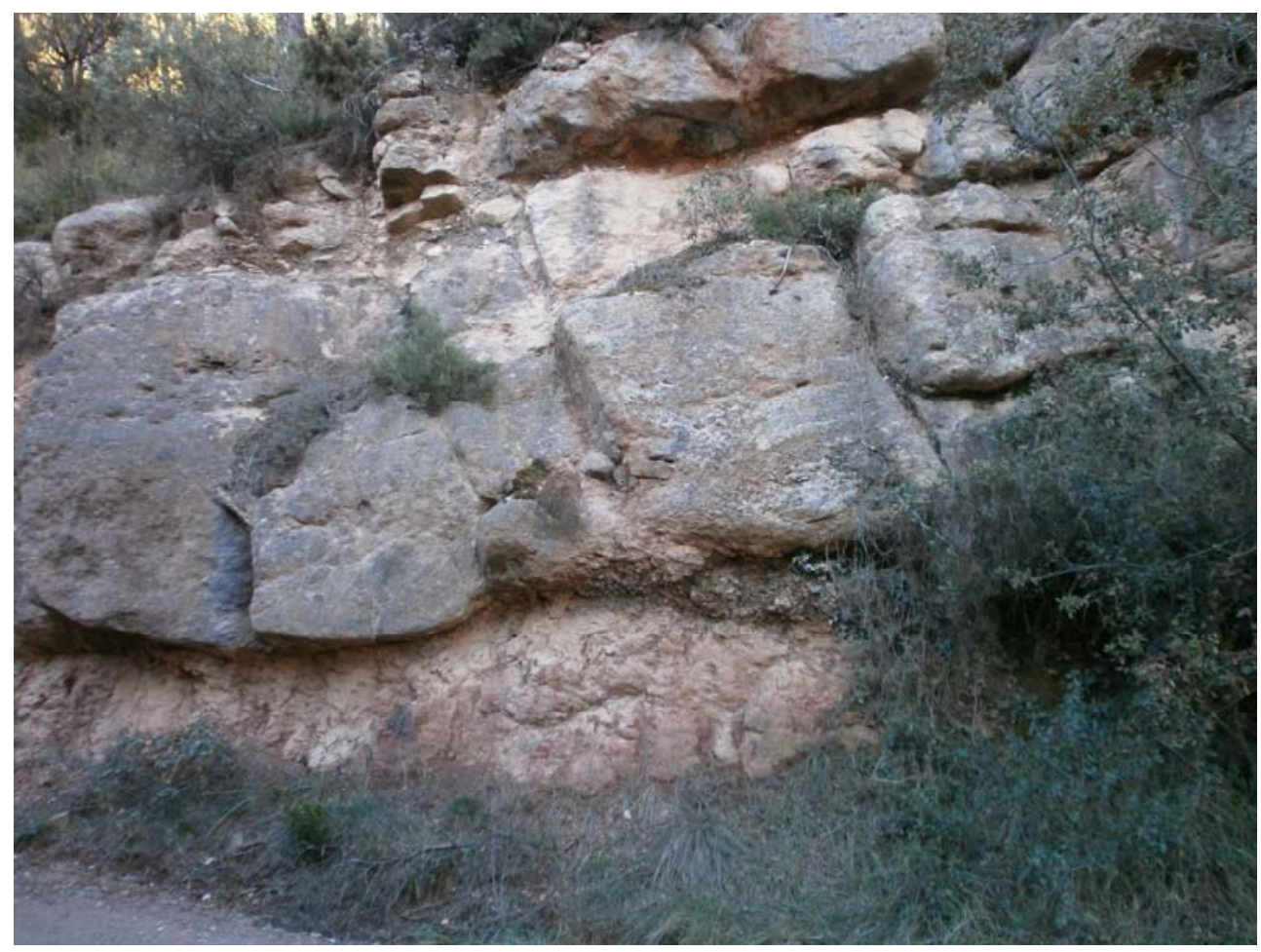

Fotografia 10. Aflorament de les bretxes de I'Eocè Inferior. Castellar del Vallès 


\subsection{Parada 9. IMMEDIACIONS DE LA FONT DE LA NOGUERA, (terme de Castellar del Vallès, comarca del Vallès Occidental). (Full 392).}

Després de fer l'aturada anterior, cal continuar baixant cap a Castellar del Vallès. Així, poc a poc, ens anirem apropant a la Font de la Noguera. En arribar a les immediacions de I'antiga tanca, farem una nova aturada, a quasi $1 \mathrm{Km}$ de I'aturada realitzada anteriorment.

En aquest recorregut, hem tornat a trobar afloraments dels materials carbonatats del Muschelkalk Inferior. És a dir, hem tornat a entrar a la Serralada Prelitoral Catalana. Aquest materials encavalquen als eocènics $i$ als paleocènics que hem anat trobant en aquest recorregut.

En aquest indret, hi ha un aflorament de les calcàries triàsiques del Muschelkalk Inferior, en un indret que correspon a una antiga explotació minera. (fotografia 11).

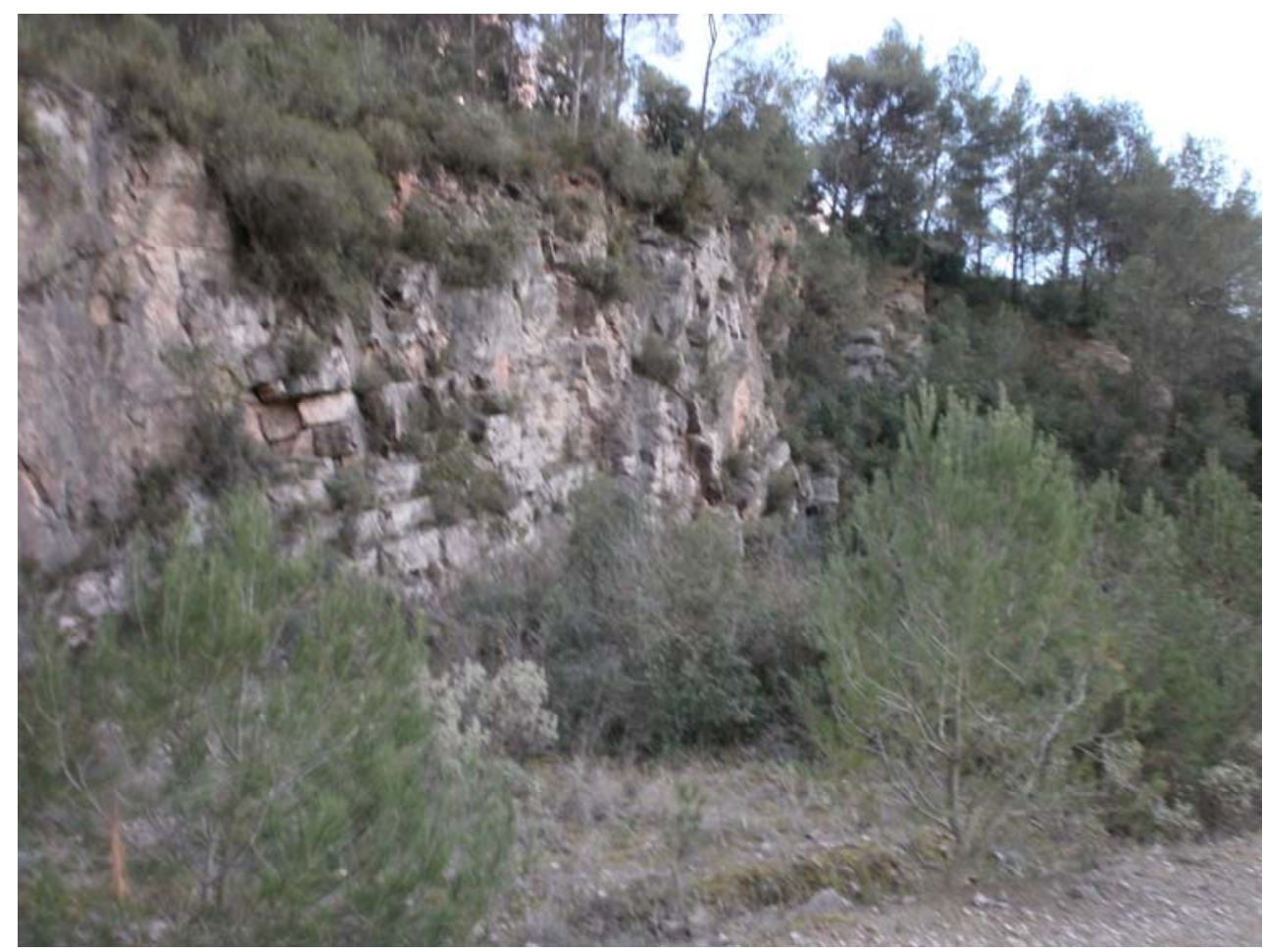

Fotografia 11. Aflorament dels materials carbonatats (calcàries) del Muschelkalk Inferior. Castellar del Vallès

En aquest indret finalitza el recorregut de l'itinerari. 


\section{Bibliografia}

GUIMERÀ, J. et altri (1992).- Geologia (II), Història Natural dels Països Catalans, Vol.2, 547 pag. Enciclopèdia Catalana, S.A. Barcelona.

IGME (1976).- Mapa Geológico de España a escala 1:50.000 (segunda Série). Hoja y memória de la hoja no 392 (Sabadell). Inst. Geol. Minero de España. Minist. Indústria. Madrid.

MATA - PERELLÓ, J.M. (1991).- Els Minerals de Catalunya. Arxius de la Secció de Ciències, t. XCIII, 442 pag. Institut d’Estudis Catalans. Barcelona.

RIBA, O. et altri (1976).- Geografia Física dels Països Catalans, Edit. Ketres, 217 pag. Barcelona. 